\title{
Activation of systemic acquired resistance in citrus to control huanglongbing disease
}

\section{Ativação da resistência sistêmica adquirida em citros para controle do huanglongbing}

\author{
Thiago Zanoni Bagio ${ }^{1}$; Marcelo Giovanetti Canteri²; \\ Thales Pereira Barreto ${ }^{3}$; Rui Pereira Leite Júnior ${ }^{4 *}$
}

\begin{abstract}
Huanglongbing (HLB) is considered the most destructive citrus disease and occurs in the major citrus producing areas around the world. In Brazil, HLB is associated with the bacteria 'Candidatus' Liberibacter asiaticus (CLas) and 'Candidatus' Liberibacter americanus (CLam). CLas is the most aggressive and widespread species of the HLB bacteria. Currently, there is no curative control measure for this disease, and the eradication of diseased trees and control of the insect vector are the basic management measures for HLB. The search for other measures with higher efficiency and lower economic and environmental impacts for control of HLB has become a research priority. The use of chemicals that activate plant resistance mechanisms is a novel method for disease control. Thus, the objective of this study was to investigate the use of systemic acquired resistance (SAR) inducers for control of HLB. Nursery trees of Valencia sweet orange (Citrus sinensis (L.) Osbeck) grafted on Rangpur lime (Citrus limonia Osbeck) were inoculated with CLas by bud grafting technique using diseased material from HLB citrus trees, seven days after the first treatment with the SAR inducers, under greenhouse conditions. The SAR inducers imidacloprid (IMI), thiamethoxan (TMX), or acibenzolar-S-methyl (ASM), as well as the combination of ASM with IMI or TMX, were applied as soil drench. The nursery trees were evaluated according to the presence of HLB symptoms and the bacterium in leaf tissue. The presence of CLas was determined by using the PCR technique, at 120,180, 240, and 300 days after the HLB bacterium inoculation. The first symptoms of HLB were observed on mature leaves of the check citrus trees 60 days before these symptoms were observed on trees treated with the SAR inducers. Two years after inoculation, $67 \%$ fewer citrus trees with HLB symptoms were observed for the ASM + TMX treated trees as compared to the check ones. Citrus trees treated with IMI, TMX, or ASM also provided lower levels of PCR-detected HLB bacterium compared to the untreated trees.
\end{abstract}

Key words: Acibenzolar-S-methyl. 'Candidatus' Liberibacter asiaticus. Citrus spp. Imidacloprid. Neonicotinoids. Thiamethoxan.

\section{Resumo}

Huanglongbing (HLB) é considerada a mais destrutiva doença para a citricultura, e ocorre nos principais países produtores de citros ao redor do mundo. No Brasil, o HLB está associado às bactérias 'Candidatus' Liberibacter asiaticus (CLas) e 'Candidatus'Liberibacter americanus (Clam), sendo a primeira espécie a mais agressiva e disseminada nos pomares brasileiros. Atualmente, não existe controle curativo para

\footnotetext{
${ }^{1}$ Eng $^{\circ}$ Agr $^{\circ}$, M.e Discente do Curso de Pós-Graduação em Agronomia, Universidade Estadual de Londrina, UEL, Londrina, PR, Brasil. E-mail: bagio.t.z@gmail.com.br

${ }^{2}$ Eng $^{\circ}$ Agr ${ }^{\circ}$, Prof. Dr., Curso de Agronomia, UEL, Londrina, PR, Brasil. E-mail: canteri@uel.br

${ }^{3}$ Eng $^{\circ}$ Agr $^{\circ}$, M.e, Syngenta, Vitória, ES, Brasil. E-mail: thales.barreto@syngenta.com

${ }^{4}$ Eng $^{\circ}$ Agr $^{\circ}$, Dr. Pesquisador, Instituto Agronômico do Paraná, IAPAR, Londrina, PR, Brasil. E-mail: ruileite@iapar.br

* Author for correspondence
} 
esta doença, sendo a erradicação de plantas doentes e o controle do inseto vetor as medidas básicas para o manejo do HLB. A busca por outras medidas de maior eficiência e de menor impacto econômico e ambiental para o controle do HLB tem se tornado prioridade para diversos grupos de pesquisa. A utilização de produtos que ativam os mecanismos de resistência das plantas é uma das principais linhas de investigação. Assim, o objetivo deste estudo foi avaliar produtos indutores da resistência sistêmica adquirida (RSA) para controle do HLB. Mudas de laranja Valência (Citrus sinensis (L.) Osbeck), enxertadas sobre limão Cravo (Citrus limonia Osbeck) foram inoculadas com CLas pela enxertia de borbulhas provenientes de plantas com HLB, sete dias após o primeiro tratamento com indutores da RSA. Os tratamentos consistiram na aplicação, via solo, de imidaclopride (IMI), tiametoxam (TMX) ou acibenzolar-S-metil (ASM), e também da combinação do ASM com os neonicotinóides IMI e TMX. As plantas foram avaliadas com base na manifestação de sintomas de HLB e na presença da bactéria nas plantas cítricas. A presença da bactéria CLas foi determinada utilizando a técnica de PCR, aos 120, 180, 240 e 300 dias após a inoculação das plantas cítricas. Os primeiros sintomas de HLB foram observados em folhas maduras das plantas controle 60 dias antes do que nas plantas tratadas com os neonicotinóides IMI e TMX e o indutor de resistência ASM. Dois anos após a inoculação, foram observadas $67 \%$ menos plantas com sintomas de HLB no tratamento com ASM + TMX do que no controle. Plantas cítricas tratadas com IMI, TMX ou ASM também apresentaram menores índices de presença da bactéria do HLB nos testes de PCR do que plantas não tratadas.

Palavras-chave: Acibenzolar-S-metil. Candidatus Liberbacter asiaticus. Citrus spp. Imidaclopride. Neonicotinóides. Tiametoxam.

\section{Introduction}

Huanglongbing (HLB) is the most destructive disease for the citrus industry in most of the main producing areas worldwide (BOVÉ, 2006). Diseased citrus trees exhibit yellowish branches, asymmetric yellow leaf blotches, and underdeveloped and deformed fruits, with inverted coloring (BOVÉ, 2006). Fruits of HLB diseased trees are not suitable for both, the juice industry and the fresh fruit market (DAGULO et al., 2010). Diseased citrus trees become economically unproductive a few years after showing the first symptoms of the disease (BASSANEZI et al., 2011).

HLB is associated with the non-cultured, fastidious, and phloem restricted bacteria 'Candidatus' Liberibacter asiaticus (CLas), 'Candidatus' Liberibacter africanus (CLaf), and 'Candidatus' Liberibacter americanus (CLam) (BOVÉ, 2006). These bacteria are transmitted by phloem-feeding insects, and the most important vectors are the psyllids Diaphorina citri Kuwayama and Trioza erytreae Del Guerico (Homoptera: Psylloidea) (CAPOOR et al., 1967). In Brazil, only CLas and CLam species were reported (COLETTAFILHO et al., 2004; TEIXEIRA et al., 2005), and the first occurrence of the disease was in the state of Sao Paulo, in 2004 (COLETTA-FILHO et al., 2004; TEIXEIRA et al., 2005). Currently, HLB is also present in the states of Minas Gerais and Paraná (BELASQUE JÚNIOR et al., 2009). Furthermore, the citrus psyllid D. citri is the vector of the HLB bacteria in Brazil (TEIXEIRA et al., 2005). The characteristics of the bacterium transmission by the insect vector have been a key factor for the establishment of a management program of the disease in different citrus growing regions in Southern Brazil (BOVÉ, 2006). The basic strategies adopted for the prevention and suppression of HLB involves regular inspections of orchards and prompt elimination of diseased trees, reduction of the $D$. citri psyllid population by regular application of insecticides, and planting of healthy citrus nursery trees produced under insect proof protected environment (BELASQUE JÚNIOR et al., 2009). These measures have allowed to slower the progress of the disease at economically acceptable levels and to prevent the spread of the pathogen to new areas, especially when applied at a regional level (BELASQUE JÚNIOR et al., 2009).

The lack of genetic resistance in citrus for HLB is the main reason for the search of alternative 
measures for disease control. In recent years, systemic acquired resistance (SAR) has been studied as a new disease control strategy for different cultivated crop plants. The results of SAR studies have been highly promising for use in the integrated management of diseases, particularly for those in which conventional control measures have been less effective (BARROS et al., 2010; PASCHOLATI, 2003). Plants have natural protection mechanisms that can be activated in response to infection by a pathogen or by resistance inducers (DURRANT; DONG, 2004; TAIZ; ZEIGER, 2004; VAN LOON et al., 2006). Some resistance inducers can activate the systemic induced resistance (SIR), whereas other inducers activate the systemic acquired resistance (SAR). SAR plays an important role in a systemic nonspecific defense mechanism effective against different biotrophic pathogens (STICHER et al., 1997; TERRY; JOYCE, 2004). Currently, several chemicals have been studied as potential SAR inducing agents in plants. The neonicotinoid insecticides thiamethoxam (TMX) and imidacloprid (IMI), and the salicylic acid and its analogs are among the main SAR inducers under study for the control of different diseases in plants (CASTRO; PEREIRA, 2008; FORD et al., 2010; FRANCIS et al., 2009; PAPPU et al., 2000).

Thus, the objective of this study was to evaluate the effectiveness of systemic neonicotinoid insecticides and the resistance inducer acibenzolar$S$-methyl (ASM) as SAR inducers for the control of HLB in citrus.

\section{Materials and Methods}

\section{Citrus trees}

Nursery trees of Valencia sweet orange (Citrus sinensis (L.) Osbeck), grafted on Rangpur lime (Citrus limonia Osbeck), were obtained from a commercial nursery. The nursery trees were planted in $3.5 \mathrm{~L}$ plastic bags containing the commercial substrate Plantmax ${ }^{\circledR}$ (Eucatex, São Paulo, SP, Brazil). The plants were kept in a greenhouse, with mean temperature of $24^{\circ} \mathrm{C}$. Pest control was carried out by foliar application of insecticides and mitecides every two weeks. The citrus trees were fertilized weekly by application of a solution containing 0.005 mol L-1 calcium nitrate, $0.004 \mathrm{~mol} \mathrm{~L}^{-1}$ potassium nitrate, monoammonium phosphate and magnesium sulfate, $0.0004 \mathrm{~mol} \mathrm{~L}^{-1}$ copper sulfate; and 0.0001 mol L-1 iron chelate. The source of micronutrients was Yogen $5^{\circledR}$ (Mitsui Fertilizantes, Rio de Janeiro, RJ, Brazil), with foliar applications at a dosage of $2.5 \mathrm{~g} \mathrm{~L}^{-1}$ every 15 days.

Inoculations of the Valencia sweet orange trees were performed using plant material obtained from field trees of Pera Rio sweet orange (C. sinensis) with characteristic symptoms of HLB. For inoculations, two buds were grafted on opposite sides of the stem of each citrus tree, around 5 to $10 \mathrm{~cm}$ above the graft line. Twelve months after the first inoculation, all trees were subjected to a severe pruning, and 30 days later, they were inoculated again, independent of the viability of the first tissue grafting. The presence of HLB bacterium in the tree sources of inoculum was confirmed by PCR test, using the primers A2 and J5, specific for CLas (HOCQUELLET et al., 1999).

\section{Treatments and experimental design}

The neonicotinoids IMI (Confidor $700 \mathrm{WG}^{\circledR}$ ) and TMX (Actara $500 \mathrm{WG}^{\circledR}$ ), and the bioactivator ASM (Bion $500 \mathrm{WG}^{\circledR}$ ) were evaluated as resistance inducers. ASM was also tested in combination with IMI and TMX. The Valencia trees were treated two to four times with the chemicals, by soil drench of $200 \mathrm{ml}$ of solution in each tree, at 60 day intervals (Table 1). The first application was 7 days before the inoculation of the citrus trees. The control trees received the same volume of water (Table 1). The experimental design was complete randomized, with six treatments and 10 replicates. Each replicate consisted of one citrus tree. The data were analyzed using the Cochran Q test for dichotomized data with more than three datasets of the same sample size (AYRES et al., 2007). 
Table 1. Treatments for activation of the systemic acquired resistance (SAR) for control of HLB control in citrus trees under greenhouse conditions.

\begin{tabular}{cccccc}
\hline \multirow{2}{*}{ Treatment $^{1}$} & $\begin{array}{c}\text { Dosage of active } \\
\text { ingredient (a.i. })^{2}\end{array}$ & \multicolumn{4}{c}{ Timing of application $^{3}$} \\
\cline { 3 - 5 } & $0.75 \mathrm{~g}$ & $\mathrm{X}$ & $\mathrm{X}$ & 3 & 4 \\
\hline TMX & $3.00 \mathrm{~g}$ & $\mathrm{X}$ & $\mathrm{X}$ & - & - \\
IMI & $0.10 \mathrm{~g}$ & $\mathrm{X}$ & $\mathrm{X}$ & $\mathrm{X}$ & - \\
ASM & $0.75 \mathrm{~g}+0.10 \mathrm{~g}$ & $\mathrm{X}+\mathrm{X}$ & $\mathrm{X}+\mathrm{X}$ & $-+\mathrm{X}$ & $-+\mathrm{X}$ \\
ASM/TMX & $3.00 \mathrm{~g}+0.10 \mathrm{~g}$ & $\mathrm{X}+\mathrm{X}$ & $\mathrm{X}+\mathrm{X}$ & $-+\mathrm{X}$ & $-+\mathrm{X}$ \\
ASM/IMI & - & $\mathrm{X}$ & $\mathrm{X}$ & $\mathrm{X}$ & $\mathrm{X}$ \\
CHECK & &
\end{tabular}

${ }^{1}$ TMX, thiamethoxam; IMI, imidacloprid; ASM, acibenzolar-S-methyl; ASM/TMX, acibenzolar- $S$-methyl + thiamethoxam, ASM/ IMI, acibenzolar-S-methyl + imidacloprid and CHECK, water; ${ }^{2}$ The products were applied individually to each tree by soil drench using a volume of $200 \mathrm{~mL} ;{ }^{3}$ The first application was performed seven days before the inoculation of the citrus trees and repeated at 60 day intervals; ${ }^{4} \mathrm{X}$, product application and -, without application of the product.

\section{Evaluations of the citrus trees}

The citrus trees were evaluated based on disease symptoms and presence of the HLB bacterium at 4 , 8,10 , and 12 months after inoculation. For disease symptoms, the trees were visually examined for the presence of typical HLB symptoms, such as asymmetric mottling and thickening of veins in mature leaves. Further, the presence of CLas was determined based on the polymerase chain reaction (PCR) test using specific primers for the bacterium (HOCQUELLET et al., 1999).

\section{DNA extraction of the citrus trees and PCR test for the detection of CLas}

Total DNA was extracted from $500 \mathrm{mg}$ of the midrib of mature leaves, by using the protocol described by Murray and Thompson (1980). The detection of CLas was by conventional PCR technique, using the primers $\mathrm{A} 2$ and $\mathrm{J} 5$, which amplify a 703 base-pair DNA fragment specific to CLas bacterium (HOCQUELLET et al., 1999). The samples were subjected to a 35 cycles including the following steps: denaturing at $92^{\circ} \mathrm{C}$ for 20 $\mathrm{s}$, annealing at $62^{\circ} \mathrm{C}$ for $20 \mathrm{~s}$, and extension at $72^{\circ} \mathrm{C}$ for $45 \mathrm{~s}$. Afterward, the reaction product was applied in $1 \%$ agarose gel, stained with $7 \mu \mathrm{L}$ of ethidium bromide $\left(10 \mathrm{mg} \mathrm{ml}^{-1}\right)$ per $100 \mathrm{~mL}$ of gel, and subjected to electrophoresis. The DNA bands were visualized under ultraviolet light and the image was captured with an L-PIX HE imaging system (Loccus Biotecnologia ${ }^{\circledR}$, Cotia, SP).

\section{Results and Discussion}

The success in the inoculation of the citrus trees with buds containing HLB bacteria inoculum was determined 30 days after inoculation, for each of the two inoculations performed. Following the first inoculation, $80 \%$ of plants had at least one viable bud (i.e., green in color and fully healed to the recipient tree) in treatments TMX, ASM, IMI, and ASM/ TMX. The control and ASM/IMI treatments had $70 \%$ and $60 \%$ inoculated bud viability, respectively. Following the second inoculation, $100 \%$ of the buds were viable in all treatments. The lower proportion of viable buds observed following the first inoculation may have interfered with the transmission of CLas bacteria in the different treatments. However, with the second inoculation all citrus trees were equally infected with the HLB bacterium.

The transmission efficiency of the HLB bacterium to citrus trees by grafting depends on several factors, such as branch source, time of the year, size of the buds to be grafted, and efficiency of the grafting (LOPES; FRARE, 2008). Although the inoculum buds were obtained from trees with severe disease symptoms and confirmed by PCR, 
the distribution of HLB bacteria is uneven in the citrus trees, even in symptomatic branches, and this must be considered in the transmission efficiency of the bacterium by grafting (COLETTA-FILHO et al., 2010; TATINENI et al., 2008). Thus, these factors may explain the $90 \%$ transmission rate of HLB bacteria in the control trees, based on symptoms (Table 2). Using the PCR test, the detection of the bacterium was lower than $60 \%$ (Table 2 ). This result can also be related to the uneven distribution of the bacterium in the citrus tree tissues (TATINENI et al., 2008). Further, this transmission efficiency of CLas was also observed in other studies in which transmission was performed by grafting using contaminated material (LOPES; FRARE, 2008). Similar results were also obtained with sweet orange trees by bud grafts contaminated with CLas in Rangpur lime rootstocks (COLETTA-FILHO et al., 2010). Nevertheless, the use of more sensitive techniques than conventional PCR to detect HLB bacteria could reveal a larger number of trees infected by the bacterium (TATINENI et al., 2008).

Table 2. Presence of Candidatus Liberibacter asiaticus based on PCR test using the primer A2 and J5, and incidence of Huanglongbing symptoms in Valencia sweet orange trees (Citrus sinensis (L.) Osbeck) treated with neonicotinoids and acibenzolar-S-methyl under greenhouse conditions.

\begin{tabular}{|c|c|c|c|c|c|c|c|c|c|c|}
\hline \multirow{3}{*}{ Treatment $^{1}$} & \multicolumn{8}{|c|}{ Trees with PCR positive for HLB bacterium (\%) } & \multirow{2}{*}{\multicolumn{2}{|c|}{$\begin{array}{c}\text { HLB symptomatic } \\
\text { trees (\%) } \\
\begin{array}{c}\text { Months after first } \\
\text { inoculation }\end{array}\end{array}$}} \\
\hline & \multicolumn{8}{|c|}{ Months after first inoculation ${ }^{2}$} & & \\
\hline & 4 & 8 & 10 & 12 & 16 & 20 & 22 & 24 & 12 & 24 \\
\hline ASM/TMX & 0 & 0 & 0 & 12 & 20 & 0 & 10 & 10 & 60 & 30 \\
\hline ASM & 0 & 0 & 0 & 0 & 40 & 40 & 40 & 40 & 50 & 50 \\
\hline ASM/IMI & 0 & 33 & 33 & 33 & 20 & 30 & 40 & 40 & $\mathrm{ND}^{3}$ & ND \\
\hline IMI & 0 & 12 & 25 & 37 & 50 & 50 & 50 & 50 & ND & ND \\
\hline TMX & 0 & 12 & 12 & 12 & 40 & 40 & 60 & 60 & 50 & 60 \\
\hline CHECK & 0 & 28 & 0 & 28 & 30 & 40 & 60 & 60 & 70 & 90 \\
\hline p-value ${ }^{4}$ & n.s. & n.s. & n.s. & 0.039 & n.s. & 0.005 & 0.006 & 0.006 & 0.001 & 0.010 \\
\hline
\end{tabular}

${ }^{1} \mathrm{ASM} / \mathrm{TMX}$, acibenzolar-S-methyl + thiamethoxam; ASM, acibenzolar-S-methyl; ASM/IMI, acibenzolar- $S$-methyl + imidacloprid; IMI, imidacloprid; TMX, thiamethoxam and CHECK, water; ${ }^{2}$ Thirteen months after the first inoculation, the citrus trees were subjected to a second inoculation; ${ }^{3} \mathrm{ND}$, not determined due to widespread symptoms of phytotoxicity caused by imidacloprid; ${ }^{4}$ Cochran Q Test for dichotomized data.

Citrus trees treated with resistance inducers showed slower development of HLB symptoms when compared with the control trees. In control trees, the first symptoms of HLB were observed in mature leaves, presenting mild asymmetric mottling, approximately four months after the first inoculation. In contrast, trees that received applications of resistance inductors showed mild symptoms of HLB six months after inoculation. Severe symptoms of the disease were observed in control trees at the end of the first year of assessment. Thirty days after the pruning performed at the end of the first evaluation year, mild symptoms of HLB were observed in new branches in all previously symptomatic trees, including control trees and those that were treated with resistance inducers. In these trees, the initial symptoms of HLB progressed rapidly over the course of the second year of evaluation, and it was not possible to observe differences in the severity of symptoms among treatments (data not shown).

The trees treated with IMI and ASM/IMI presented symptoms of phytotoxicity after receiving the second application of these products. The symptoms of phytotoxicity were similar to 
those of nutritional deficiency, with generalized internerval chlorosis, progressing to the edges of the leaves. These symptoms remained throughout the experimental period, even after the pruning of the branches.

The incidence of HLB was quantified by considering only the trees that showed at least one viable inoculum bud. Therefore, the IMI treatment had the highest incidence of diseased trees in the first year, with $37 \%$ of trees with positive PCR result for CLas (Table 2). Control and ASM/IMI treatments, presented only two trees with positive PCR results for the HLB bacterium, with an incidence of $28 \%$ and $33 \%$ of diseased trees, respectively (Table 2). It is worth noting that the difference in percentage of diseased trees was due to differences of viable buds among the treatments. None of the trees treated with ASM showed positive PCR results for HLB bacteria in the first year of the study (Table 2).

At the end of the second experimental year, when the citrus trees had already been inoculated by the second time, the treatments with higher incidence of HLB were the control and TMX, both with $60 \%$ of CLas-infected trees (Table 2). The treatments with ASM alone and in association with neonicotinoids had $10 \%$ to $40 \%$ infected trees (Table 2). The treatment with ASM plus TMX had the lowest number of trees with CLas, based on PCR tests (Table 2). Therefore, we can infer that synergism possibly occurred between ASM and TMX products for control of the HLB bacterium.

The neonicotinoids and ASM are capable of inducing SAR in various cultivated plants (CAVALCANTI et al., 2006; FRANCIS et al., 2009; MANDAL et al., 2008). Applications of ASM reduced the number of lesions caused by Xanthomonas citri subsp. citri in citrus trees artificially inoculated (FRANCIS et al., 2009; GRAHAM; LEITE JÚNIOR, 2007; SILVA et al., 2012). These results indicate that the resistance mechanisms of citrus trees remain active for a certain period after treatment with resistance inducers (FRANCIS et al., 2009; GRAHAM; LEITE JÚNIOR, 2007; SILVA et al., 2012). SAR involves the activation of latent mechanisms in the plant, providing systemic resistance to phytopathogenic microorganisms, even when the infection site is distant from where the inducer was applied (DURRANT; DONG, 2004; RYALS et al., 1996).

Activation of SAR is characterized by the accumulation of salicylic acid, the expression of genes that encode proteins related to pathogenicity (PR), and hypersensitivity reactions (HR) (RESENDE et al., 2003). The application of resistance inducers before inoculating the pathogen was intended to induce a prior activation of the resistance mechanisms of the plant in order to contain the infection. The speed of response of the plant to the stimuli caused by the infection process is crucial for the success or failure of the development of diseases (RESENDE et al., 2003).

Based on transcriptome studies, it was demonstrated that citrus trees naturally infected with CLas had activation of SAR, although inefficiently (MARTINELLI et al., 2013). A higher production of aminobutyric acid (ABA) was observed in symptomatic citrus fruit, interfering with the biosynthesis of jasmonic acid (JA), a resistance inducer against necrotrophic pathogens (PIETERSE et al., 2009). This process is antagonistic to defense pathways dependent on salicylic acid (SA), which is responsible for defense mechanisms against biotrophic pathogens (MARTINELLI et al., 2013). The biosynthesis of JA can also be induced by the feeding process of the insect vector of the HLB bacterium. This could cause delay in tree response of more efficient defense mechanisms against CLas. In the same study, Martinelli et al. (2013) demonstrated the induction of the methyl salicylic acid pathway in young leaves of citrus trees infected with CLas. However, signaling for the defense response pathway dependent on this acid was not detected. Young tree organs are preferred for feeding by the insect vector of the HLB bacterium, 
and this is possibly where there is larger probability of bacterium infection. The low efficiency in the expression of plant defense mechanisms at the primary site of infection reinforces the hypothesis of the suppression of the plant defense responses mediated by gene homologous to hydroxylase salicylate (sahA), found in the CLas genome, or even by the activation of the JA pathways through the feeding of the insect vector (ANDERSON et al., 2004; MARTINELLI et al., 2013).

Studies with transgenic tobacco plants demonstrated the non activity of salicylate hydroxylase (sahA) on molecules analogous to salicylic acid in vitro (PARK et al., 2007). This supports the hypothesis that the ability of CLas in suppressing the natural defenses of citrus tree may be dependent on the accumulation of salicylic acid in the activation of SAR under natural conditions. The use of analogues of salicylic acid in a preventive manner could be a strategy for early and effective activation of tree resistance mechanisms against HLB. The present study indicated that the preventive administration of SAR inducers in citrus trees, in particular analogues of salicylic acid, could reduce the efficiency of the colonization of citrus trees by CLas. Further studies using a larger number of trees inoculated with $D$. citri, the insect vector of CLas and CLam in Brazil, should be carried out to as this is the natural conditions of the spread and transmission of HLB bacteria.

\section{Conclusions}

Applications of SAR inducers, such as the neonicotinoids IMI and TMX and the bioactivator ASM, reduce the colonization and infection efficiency of citrus trees by CLas and delay the development of HLB symptoms.

There is evidence of a synergistic effect in the induction of SAR in citrus trees when ASM and TMX are applied in combination for control of HLB.

\section{References}

ANDERSON, J. P.; BADRUZSAUFARI, E.; SCHENK, P. M.; MANNERS, J. M.; DESMOND, O. J.; EHLERT, C.; MACLEAN, D. J.; EBERT, P. R.; KAZAN, K. Antagonistic interaction between abscisic acid and jasmonate-ethylene signaling pathways modulates defence gene expression and disease resistance in arabidopsis. The Plant Cell, Waterbory, v. 16, n. 12, p. 3460-3479, 2004.

AYRES, M.; AYRES JÚNIOR, M.; AYRES, D. L.; SANTOS, A. A. BioEstat 5.0: aplicações estatísticas nas áreas das ciências biológicas e médicas. Belém: Sociedade Civil Mamirauá, 2007. 364 p.

BARROS, F. C.; SAGATA, E.; FERREIRA, L. C. C.; JULIATTI, F. C. Indução de resistência em plantas contra fitopatógenos. Bioscience Journal, Uberlândia, v. 26, n. 2, p. 231-239, 2010.

BASSANEZI, R. B.; MONTESINO, L. H.; GASPAROTO, M. C. G.; BERGAMIN-FILHO, A.; AMORIN, L. Yield loss caused by Huanglongbing in different sweet Orange cultivars in São Paulo, Brazil. Europe Journal of Plant Pathology, Wageningen, v. 130, n. 4, p. 577-586, 2011.

BELASQUE JÚNIOR, J. B.; BERGAMIN FILHO, A.; BASSANEZI, R. B.; BARBOSA, J. C.; FERNANDES, N. G.; YAMAMOTO, P. T.; LOPES, S. A.; MACHADO, M. A.; LEITE JÚNIOR, R. P.; AYRES, A. J.; MASSARI, C. A. Base científica para a erradicação de plantas sintomáticas e assintomáticas de Huanglongbing (HLB, Greening) visando o controle efetivo da doença. Tropical Plant Pathology, Brasília, v. 34, n. 3, p. 137-145, 2009.

BOVÉ, J. M. Huanglongbing: a destructive, newlyemerging, century-old disease of citrus. Journal of Plant Pathology, Bari, v. 88, n. 1, p. 7-37, 2006.

CAPOOR, S. P.; RAO, D. G.; VISWANATH, S. M. Diaphorina citri: a vector of the greening disease of citrus in India. Indian Journal of Agriculture Science, New Delhi, v. 37, n. 6, p. 572-576, 1967.

CASTRO, C.; PEREIRA, M. Bioativadores na agricultura. In: GAZZONI, D. L. (Ed.). Tiametoxam: uma revolução na agricultura brasileira. Petrópolis: Vozes, 2008. p. 118-126.

CAVALCANTI, F. R.; RESENDE, M. L. V.; ZACARONI, A. B.; RIBEIRO JÚNIOR, P. M.; COSTA, J. C. B.; SOUZA, R. M. Acibenzolar-S-metil e Ecolife ${ }^{\circledR}$ na indução de respostas de defesa do tomateiro contra a mancha bacteriana (Xanthomonas vesicatoria). Fitopatologia Brasileira, Brasília, v. 31, n. 4, p. 372-380, 2006. 
COLETTA-FILHO, H. D.; CARLOS, E. F.; ALVES, K. C. S.; PEREIRA, M. A. R.; BOSCARIOL-CAMARGO, R. L.; SOUZA, A. A. de; MACHADO, M. A. In planta multiplication and graft transmission of Candidatus Liberibacter asiaticus revealed by real-time PCR. European Journal of Plant Pathology, Wageningen, v. 126, n. 1, p. 53-60, 2010.

COLETTA-FILHO, H. D.; TARGON, M. L. P. N.; TAKITA, M. A.; NEGRI, J. D. de; POMPEU JÚNIOR, J.; AMARAL, A. M. do; MULLER, G. W.; MACHADO, M. A. First report of the causal agent of huanglongbing (Candidatus Liberibacter asiaticus) in Brazil. Plant Disease, St. Paul, v. 88, n. 12, p. 1382, 2004.

DAGULO, L.; DANYLUK, M. D.; SPANN, T. M.; VALIM, M. F.; GOODRICH-SCHNEIDER, R.; SIMS, C.; ROUSEFF, R. Chemical characterization of orange juice from trees infected with citrus greening (Huanglongbing). Journal of Food Science, Chicago, v. 75, n. 2, p. 199-207, 2010.

DURRANT, W. E.; DONG, X. Systemic acquired resistance. Annual Review of Phytopathology, Palo Alto, v. 42, n. 1, p. 185-209, 2004.

FORD, K. A.; CASIDA, J. R.; CHANDRAN, D.; GULEVICH, A. G.; OKRENT, R. A.; DURKIN, K. A.; SARPONG, R.; BUNNELLE, E. M.; WILDERMUTH, M. C. Neonicotinoid insecticides induce salicylateassociated plant defence responses. Proceedings of the National Academy of Sciences of the United States of America, Washington, v. 107, n. 41, p. 17527-17532, 2010.

FRANCIS, M. I.; REDONDO, A.; BURNS, J. K.; GRAHAM, J. H. Soil application of imidacloprid and related SAR-inducing compounds produces effective and persistent control of citrus canker. Europe Journal of Plant Pathology, Wageningen, v. 124, n. 2, p. 283-292, 2009.

GRAHAM, J. H.; LEITE JÚNIOR, R. P. Soil applied neonicotinoids for control of bacterial diseases on young citrus trees. Proceedings of International Workshop on PR-Proteins and Induced Resistance Against Pathogens and Insects. Doorn, 2007. p. 107.

HOCQUELLET, A.; TOORAWA, P.; BOVE, J. M.; GARNIER, M. Detection and identification of the two Candidatus Liberibacter species associated with citrus huanglongbing by PCR amplification of ribosomal protein genes of the $\mathrm{b}$ operon. Molecular and Cellular Probes, Amsterdam, v. 13, n. 5, p. 373-379, 1999.

LOPES, S. A.; FRARE, G. F. Graft transmission and cultivar reaction of citrus to Candidatus Liberibacter americanus. Plant Disease, St. Paul, v. 92, n. 1, p. 21-24,
2008.

MANDAL, B.; MANDAL, S.; CSINOS, A. S.; MARTINEZ, N.; CULBREATH, A. K.; PAPPU, H. R. Biological and molecular analyses of the acibenzolarS-methyl-induced systemic acquired resistance in flue-cured tobacco against tomato spotted wilt virus. Phytopathology, Saint Paul, v. 98, n. 2, p. 196-204, 2008.

MARTINELLI, F.; REAGAN, R. L.; URATSU, S. L.; PHU, M. L.; ALBRECHT, U.; ZHAO, W.; DAVIS, C. E.; BOWMAN, K. D.; DANDEKAR, A. M. Gene regulatory networks elucidating Huanglongbing disease mechanisms. Public Library of Science One, San Francisco, v. 8, n. 9, p. e74256, 2013.

MURRAY, M. G.; THOMPSON, W. F. Rapid isolation of high molecular weight plant DNA. Nucleic Acids Research, Standford, v. 8, n. 19, p. 4321-4325, 1980.

PAPPU, H. R.; CSINOS, A. S.; MCPHERSON, R. M.; JONES, D. C.; STEPHENSON, M. G. Effect of acibenzolar-S-methyl and imidacloprid on suppression of tomato spotted wilt Tospovirus in flu-cured tobacco. Crop Protection, Guildford, v. 19, n. 5, p. 349-354, 2000.

PARK, S. W.; KAIMOYO, E.; KUMAR, D.; MOSHER, S.; KLESSIG, D. Methyl salicylate is a critical mobile signal for plant systemic acquired resistance. Science, Washington, v. 318, n. 5847, p. 113-116, 2007.

PASCHOLATI, S. F. Indução de resistência sistêmica: opção para o controle de doenças de plantas no século XXI. Summa Phytopathologica, Botucatu, v. 29, n. 1, p. 115-116, 2003.

PIETERSE, C. M. J.; LEON-REYES, A.; VAN DER ENT, S.; VAN WEES, S. C. M. Networking by smallmolecule hormones in plant immunity. Nature Chemical Biology, Cambridge, v. 5, n. 1, p. 308-316, 2009.

RESENDE, M. L. V.; SALGADO, S. M. L.; CHAVES, Z. $M$. Espécies ativas de oxigênio na resposta de defesa de plantas a patógenos. Fitopatologia Brasileira, Brasília, v. 28 , n. 2, p. 123-130, 2003.

RYALS, J. A.; NEUENSCHWANDER, U. H.; WILLITS, M. G.; MOLIN, A.; STEINER, H. Y.; HUNT, M. D. Systemic acquired resistance. Plant Cell, Rockville, v. 8, n. 1, p. 1809-1819, 1996.

SILVA, M. R. L.; CANTERI, M. G.; LEITE JÚNIOR, R. P. Inseticida neonicotinóide induz resistência ao cancro cítrico em laranja doce. Tropical Plant Pathology, Brasília, v. 37, n. 1, p. 65-75, 2012.

STICHER, L.; MAUCH-MANI, B.; MÉTRAUX, J. P. Systemic acquired resistance. Annual Review of Phytopathology, Palo Alto, v. 35, n. 1, p. 235-270, 1997. 
TAIZ, L.; ZEIGER, E. Fisiologia vegetal. 3. ed. Porto Alegre: Artmed, 2004. 719 p.

TATINENI, S.; SAGARAM, U. S.; GOWDA, S.; ROBERTSON, C. J.; DAWSON, W. O.; IWANAMI, T.; WANG, N. In plants distribution of Candidatus Liberibacter asiaticus as revealed by polymerase chain reaction (PCR) and real-time PCR. Phytopathology, Saint Paul, v. 98, n. 5, p. 592-599, 2008.

TEIXEIRA, D. C.; DANET, J. L.; EVEILLARD, S.; MARTINS, E. C.; JESUS JUNIOR, W. C.; YAMAMOTO, P. T.; LOPES, S. A.; BASSANEZI, R. B.; AYRES, A. J.; SAILLARD, C.; BOVÉ, J. M. Citrus huanglongbing in São Paulo State, Brazil: PCR detection of the Candidatus Liberibacter species associated with the disease. Molecular and Cellular Probes, Amsterdam, v. 19, n. 3, p. 173-179, 2005.

TERRY, L. A.; JOYCE, D. C. Elicitors of induced disease resistance in postharvest horticultural crops: a brief review. Postharvest Biology and Technology, Amsterdam, v. 32, n. 1, p. 1-13, 2004.

VAN LOON, L. C.; REP, M.; PIETERSE, C. M. J. Significance of inducible defence-related proteins in infected plants. Annual Review of Phytopathology, Palo Alto, v. 44, n. 1, p. 135-162, 2006. 
